\title{
Synthesis
}

\section{Focusing the Meaning(s) of Resilience: Resilience as a Descriptive Concept and a Boundary Object}

\author{
$\underline{\text { Fridolin Simon Brand }}^{1}$ and $\underline{\text { Kurt Jax }}^{2}$
}

\begin{abstract}
This article reviews the variety of definitions proposed for "resilience" within sustainability science and suggests a typology according to the specific degree of normativity. There is a tension between the original descriptive concept of resilience first defined in ecological science and a more recent, vague, and malleable notion of resilience used as an approach or boundary object by different scientific disciplines. Even though increased conceptual vagueness can be valuable to foster communication across disciplines and between science and practice, both conceptual clarity and practical relevance of the concept of resilience are critically in danger. The fundamental question is what conceptual structure we want resilience to have. This article argues that a clearly specified, descriptive concept of resilience is critical in providing a counterbalance to the use of resilience as a vague boundary object. A clear descriptive concept provides the basis for operationalization and application of resilience within ecological science.
\end{abstract}

Key Words: boundary object; definition; descriptive concept; ecological resilience; resilience; sustainability; typology.

\section{INTRODUCTION}

The concept of resilience is one of the most important research topics in the context of achieving sustainability (Perrings et al. 1995, Kates et al. 2001, Foley et al. 2005). First introduced as a descriptive ecological term (Holling 1973), resilience has been frequently redefined and extended by heuristic, metaphorical, or normative dimensions (e.g., Holling 2001, Ott and Döring 2004, Pickett et al. 2004, Hughes et al. 2005). Meanwhile, the concept is used by various scientific disciplines as an approach to analyze ecological as well as socialecological systems (Anderies et al. 2006, Folke 2006). As such, it promotes research efforts across disciplines and between science and policy.

However, both conceptual clarity and practical relevance are critically in danger. The original descriptive and ecological meaning of resilience is diluted as the term is used ambiguously and in a very wide extension. This is due to the blending of descriptive aspects, i.e., specifications of what is the case, and normative aspects, i.e., prescriptions what ought to be the case or is desirable as such. As a result, difficulties to operationalize and apply the concept of resilience within ecological science prevail. This, in turn, impedes progress and maturity of resilience theory (cf., Pickett et al. 1994:57). The success of the concept in stimulating research across disciplines on the one side and the dilution of the descriptive core on the other raises the fundamental question what conceptual structure we want resilience to have.

This article is divided into four parts. The first section offers a typology to structure the numerous definitions of resilience proposed within sustainability science. Using this typology as a background, the second section investigates in more detail a descriptive, ecological concept of resilience viewed from both a formal and an operational perspective. Subsequently, the third section examines the use of resilience as a rather vague boundary object and points to some chances and pitfalls. The fourth section concludes with final thoughts on the recent conceptual development and a fruitful conceptual structure of resilience. 


\section{A TYPOLOGY FOR DEFINITIONS OF RESILIENCE}

In what follows we suggest a typology for the variety of definitions of resilience used in sustainability science. The typology is based on the analysis of key papers published in the last $35 \mathrm{yr}$ (cf., Janssen et al. 2006). It provides the background for discussing the conceptual development of resilience.

Before turning to the definitions in detail some words on the terminology used are in order. First, two distinct meanings of resilience must be distinguished. The first one refers to dynamics close to equilibrium and is defined as the time required for a system to return to an equilibrium point following a disturbance event. It has been coined engineering resilience (Holling 1996) and is largely identical to the stability property, i.e., elasticity (Grimm and Wissel 1997). The second meaning of resilience refers to dynamics far from any equilibrium steady state and is defined as the amount of disturbance that a system can absorb before changing to another stable regime, which is controlled by a different set of variables and characterized by a different structure. It has been termed ecosystem resilience (Gunderson and Holling 2002) and it is applied almost interchangeable with the words ecological resilience (e.g., Holling 1996, Holling et al. 1997, Gunderson 2000, Gunderson and Pritchard 2002, Anderies et al. 2006) or resilience (e.g., Holling 1973, 1986, Arrow et al. 1995, Perrings et al. 1995, Carpenter and Cottingham 1997, Carpenter et al. 2001, Walker et al. 2002, 2004, Bellwood et al. 2004, Folke et al. 2004, Carpenter and Folke 2006). It is this second kind of resilience to which we refer in this text.

The result of our analysis is displayed in Table 1. It shows 3 categories, 10 classes, and correspondingly 10 definitions of resilience. The three categories reflect whether the definition is in accordance with either a genuinely descriptive concept (Category I), a hybrid concept, in which descriptive and normative connotations are intermingled (Category II), or a genuinely normative concept (Category III). Thus, our scheme in the first place emphasizes the degree of normativity included in the different definitions that fit under the overall category of resilience as characterized above. However, we also found it useful and necessary to distinguish between purely ecological definitions, i.e., Class 1-4, and those which are also used in the context of other fields such as economy and sociology, i.e., Class 510.

In the following, each definition of resilience is explained in more detail with respect to its category and class, respectively. Note that the proclaimed titles do not correspond to the particular references.

\section{Category I: Descriptive concept}

\section{Sub-category Ia: Ecological science}

\section{Class 1: Original ecological definition}

In his seminal paper, Holling (1973) defines resilience as a "measure of the persistence of systems and of their ability to absorb change and disturbance and still maintain the same relationships between populations or state variables" (Holling 1973:14). In this original-ecological meaning, resilience focuses on the persistence of populations or communities at the ecosystem level and corresponds to both the overall area and the height of the lowest point of a population's domain of attraction. A relative measure is a population's probability of extinction.

\section{Class 2: Extended ecological definition}

Subsequent work published from the late 1980s (Holling 1986, 1996, Walker 1999, Gunderson 2000, Gunderson and Holling 2002, Gunderson and Pritchard 2002, Walker et al. 2002, 2004) is strongly influenced by theory on complex adaptive systems (e.g., Levin 1998) including the cross-scale morphology of ecosystems (Holling 1992). According to the extended keystone hypothesis originally proposed by Holling (1992), the hierarchical structure of ecosystems is primarily regulated by a small set of plant, animal, and abiotic processes each operating over different scale ranges. Important changes in ecosystem dynamics can be understood by analyzing a few, typically no more than five, key variables (Walker et al. 2006). In this interpretation, the scientific focus is on the critical structure and processes of an ecosystem. Individual species can be replaced if the critical structure and key processes persist (Walker et al. 1999, Elmqvist et al. 2003, Nyström 2006). In this extended-ecological meaning, resilience is defined as "the magnitude of disturbance that can be absorbed before the system changes its structure by 
Table 1. Ten definitions of resilience with respect to the degree of normativity.

\begin{tabular}{lll}
\hline \hline Categories and classes & Definitions & References
\end{tabular}

\section{(I) DESCRIPTIVE CONCEPT}

(Ia) ECOLOGICAL SCIENCE

1) Original-ecological

2) Extended-ecological

2a) Three characteristics

2b) Four aspects

3) Systemic-heuristic

4) Operational

(Ib) SOCIAL SCIENCES

5) Sociological

6) Ecological-economic

\section{(II) HYBRID CONCEPT}

7) Ecosystem-services-related

\section{8) Social-ecological system}

8a) Social-ecological
Measure of the persistence of systems and of their ability to absorb change and disturbance and still maintain the same relationships between populations or state variables

The magnitude of disturbance that can be absorbed before the system changes its structure by changing the variables and processes that control behavior and

The capacity of a system to experience shocks while retaining essentially the same function, structure, feedbacks, and therefore identity

capacities i) to absorb disturbances, ii) for self-organization, and iii) for learning and adaptation

1) latitude (width of the domain),

2) resistance (height of the domain),

3) precariousness,

4) cross-scale relations

Quantitative property that changes throughout ecosystem dynamics and occurs on each level of an ecosystem's hierarchy

Resilience of what to what?

and

The ability of the system to maintain its identity in the face of internal change and external shocks and disturbances

Holling 1973:14

Gunderson and Holling 2002:4

Walker et al. 2006:2

Walker et al. 2002

Folke et al. 2004:573

Holling 2001

Carpenter et al. 2001

Cumming et al. 2005

The ability of groups or communities to cope with external stresses and disturbances as a result of social, political, and environmental change

Transition probability between states as a function of the consumption and production activities of decision makers and

The ability of the system to withstand either market or environmental shocks without loosing the capacity to allocate resources efficiently

Adger 2000:347

Brock et al.

2002:273

Perrings 2006:418

The underlying capacity of an ecosystem to maintain desired ecosystem services in the face of a fluctuating environment and human use

Folke et al. 2002:14
The capacity of a social-ecological systems to absorb recurrent Adger et al. disturbances (...) so as to retain essential structures, processes 2005:1036 and feedbacks 
8b) Resilience-approach

(III) NORMATIVE CONCEPT

9) Metaphoric

10) Sustainability-related
A perspective or approach to analyze social-ecological systems Folke 2006

Flexibility over the long term

Pickett et al. 2004:381

Ott and Döring 2004:213f changing the variables and processes that control behaviour" (Gunderson and Holling 2002:4) or "the capacity of a system to experience shocks while retaining essentially the same function, structure, feedbacks, and therefore identity" (Walker et al. 2006:2).

\section{Class 2a: Three characteristics}

Some authors interpret the extended-ecological meaning as comprising three characteristics. Those are: (1) the amount of change a system can undergo and still remain within the same domain of attraction, i.e., to retain the same controls on structure and processes; (2) the degree to which the system is capable of self-organization; and (3) the degree to which the system expresses capacity for learning and adaptation (Carpenter et al. 2001, Walker et al. 2002, Folke 2006).

\section{Class 2b: Four aspects}

One line of research emphasizes the concept of alternative stable regimes (Scheffer and Carpenter 2003, Folke et al. 2004, Walker and Meyers 2004). Note that the term "regime" is preferred to avoid the static connotations of the term "state" and to describe the actual dynamic situation of a specified ecosystem (Scheffer and Carpenter 2003). Formally, alternative stable regimes exist within alternative basins of attraction (Walker et al. 2004). Four aspects of a basin of attraction are crucial. Those are: (1) latitude or the maximum amount the system can be changed before losing its ability to recover, e.g., the width of the basin; (2) resistance, which matches the ease or difficulty of changing the system, e.g., the topology of the basin; (3) precariousness, i.e., the current trajectory of the system and proximity to a limit or threshold; and (4) cross-scale relations, or how the above three aspects are influenced by the dynamics of the systems at scales above and below the scale of interest (Folke et al. 2004, Walker et al. 2004).

Class 3: Systemic-heuristic definition

Some scholars have worked on the presuppositions of the concept of resilience, which include a heuristic for the dynamics of productive, selforganized systems, the "panarchy." This metamodel (Cumming and Collier 2005) of ecosystem dynamics consists of four-phase adaptive cycles, $i$. e., r-, K-, $\Omega$-, and $\alpha$-phases, which occur on each level of a system's hierarchy. Against this background, resilience represents a quantitative property that changes throughout the adaptive cycle and principally occurs on each level of a system's hierarchy (Holling 2001, Gunderson and Holling 2002).

\section{Class 4: Operational definition}

To apply the concept of resilience to empirical cases, it is critical to specify resilience of "what to what" (Carpenter et al. 2001). This operational definition constitutes the first step to make resilience concrete. Further operational steps suggest focusing on the concept of identity and defining resilience as "the ability of the system to maintain its identity in the face of internal change and external shocks and disturbances" (Cumming et al. 2005).

\section{Sub-category Ib: Social sciences}

Class 5: Sociological definition

Some scientists apply the concept of resilience to social systems. Social resilience is defined as "the ability of groups or communities to cope with external stresses and disturbances as a result of social, political, and environmental change" (Adger 2000:347). 
Class 6: Ecological-economical definition

In addition, the concept of resilience is used to analyze economy-environment systems (e.g., Perrings and Walker 1997, Perrings and Stern 2000, Brock et al. 2002, Perrings 2006). Resilience matches the "transition probability between states as a function of the consumption and production activities of decision makers" (Brock et al. 2002:273) or "the ability of the system to withstand either market or environmental shocks without loosing the capacity to allocate resources efficiently" (Perrings 2006:418).

\section{Category II: Hybrid concept}

\section{Class 7: Ecosystem services-related definition}

In this hybrid sense, resilience corresponds to the underlying capacity of an ecosystem to maintain desirable ecosystem services in the face of human use and a fluctuating environment (Carpenter 2001, Folke et al. 2002). Studies focus on desirable ecosystem services of an ecological system, e.g., food production, water purification, or aesthetic enjoyment (MEA 2005).

\section{Class 8: Social-ecological system.}

Many scientists state that it is critical to apply the concept of resilience to coupled social-ecological systems, as it may be a fundamental error of environmental policy to separate the human system from the natural system and treat them as independent (e.g. Folke et al. 2002, Anderies et al. 2006, Walker et al. 2006). The nature-culture split is seen as arbitrary and artificial; humans are regarded as part of the ecosystem (Westley et al. 2002, Berkes et al. 2003).

\section{Class 8a: Social-ecological definition}

Social-ecological resilience is defined as "the capacity of social-ecological systems to absorb recurrent disturbances (...) so as to retain essential structures, processes and feedbacks" (Adger et al. 2005:1036). In this approach, a system analysis tends to incorporate specific values, e.g., cultural diversity or international aid. Consequently, there is an increase in the degree of normativity, i.e., resilience gets more and more desirable as such.
Class 8b: Resilience approach

Recently, resilience has been increasingly conceived as a perspective, as a way of thinking to analyze linked social-ecological systems (Folke 2006). No clear definition is suggested. Rather, resilience is conceived as a collection of ideas about how to interpret complex systems (Anderies et al. 2006).

\section{Category II: Normative concept}

Class 9: Metaphorical definition

In a metaphoric interpretation, the concept of resilience means "flexibility over the long term" (Pickett et al. 2004:381) and is viewed as desirable as such.

\section{Class 10: Sustainability-related definition}

Resilience has been suggested as to be one of the guidelines for a conception of strong sustainability (Ott 2001, 2003, Ott and Döring 2004). Hereby the term refers to the maintenance of natural capital in the long-term in order to provide ecosystem services that provide instrumental as well as eudaemonistic values for human society.

These ten definitions together represent the intension of the term resilience. Even though they are all related to the original, descriptive concept of resilience, as introduced by Holling (1973), the term has been transformed considerably. The conceptual development of resilience has been recently reviewed by Folke (2006), who made a distinction between an early interpretation of resilience, which focuses on the robustness of systems to withstand shocks while maintaining function, i.e., ecosystem or ecological resilience, social resilience, and a subsequent interpretation, which refers more to the interplay of disturbance and reorganization within a system as well as to transformability, learning and innovation, i.e., social-ecological resilience. Although Folke (2006) points to the change in the specific meaning of resilience our own interpretation of the conceptual development of resilience highlights the distinct use of the concept of resilience within the spectrum of scientific disciplines. Thus, the subsequent sections contrast (a) a clearly specified concept of resilience that is merely used in ecology with (b) a vague and 
malleable concept of resilience that is used as a communication tool across different scientific disciplines and between science and practice.

\section{RESILIENCE AS A DESCRIPTIVE ECOLOGICAL CONCEPT}

This section describes a descriptive, ecological concept of resilience in more detail. By definition a descriptive concept of resilience excludes normative dimensions. Resilience may be viewed as either desirable or undesirable in a specific case; this depends on the state of concern. This means, a degraded savannah or a polluted lake can be highly resilient but at the same time undesirable from an anthropocentric perspective (Carpenter et al. 2001, Carpenter and Cottingham 2002, Walker et al. 2002).

In a descriptive sense, the concept of resilience points to a nonequilibrium view on ecological systems (Wallington et al. 2005), that is, it assumes the existence of alternative stable regimes (Holling 1996). For example, a savannah may exhibit either a locally stable grassy regime or a locally stable woody regime depending on the value of some driving factors, such as rainfall, grazing pressure and fire events (Walker 2002). There is strong evidence that most ecosystem types can exist in alternative stable regimes, for instance lakes, coral reefs, deserts, rangelands, woodlands, and forests (Folke et al. 2004, Walker and Meyers 2004). However, the weight of empirical evidence shows that the relative frequency of the occurrence of alternative stable regimes across systems is higher for systems controlled by environmental adversity, e.g., deserts, arctic tundra, or savannahs, than those controlled by competitive adversity, e.g., forests or coral reefs (Didham 2006).

A mathematical model of this behavior termed "bistability" is provided by phase plane and bifurcation diagrams proposed by Ludwig et al. (1997, 2002). Formally a system exhibits alternative basins of attraction when a fast state variable, e.g., annual grasses, macrophytes, responds to changes in a slow variable, e.g., long-lived organisms, nutrient storages, by a backward-folding curve, as shown in Fig. 1. Because of the backward fold, two stable basins overlap, separated by an unstable one over a given range of the slow variable (Scheffer et al. 2001, Scheffer and Carpenter 2003, Schröder et al. 2005).
When the system is in a regime on the upper blue branch of the folded curve in Fig. 1, it cannot pass to the lower green branch smoothly. Instead, when the slow variable changes sufficiently to pass the critical value, i.e., the ecological threshold $\left(E T_{1}\right)$, a catastrophic transition to the lower branch occurs, either caused by only an incremental change in conditions or due to a bigger disturbance. To induce a switch back to the upper branch it is not sufficient to restore the slow variable to the value before the collapse. Instead, one needs to go back further, beyond the other switch point $\left(E T_{2}\right)$, at which the system recovers by shifting back to the upper branch, a pattern known as "hysteresis" (Scheffer and Carpenter 2003, Groffman et al. 2006, Briske et al. 2006). In contrast to a narrow equilibrium view, this indicates the importance of the boundaries of a basin of attraction and the ease or difficulty with which a system could be moved out of this basin (Holling 1973, 1996, Gunderson and Holling 2002).

For example, shallow lakes can exhibit two stable regimes with respect to nutrient load, i.e., a clearwater regime with aquatic plants and a turbid regime without vegetation. If the lake is in the clear-water regime, an increase of the nutrient level will lead to a gradual and moderate rise in turbidity until the critical turbidity for plant survival is reached. At this point, vegetation collapses and the lake shifts to the turbid regime. Reduction of nutrients after this catastrophic transition does not result in a return of plants immediately. However, the backward switch happens at much lower nutrient level than the forward switch. Thus, often reduction of the nutrient level to values at which the lake used to be clear and vegetated will not lead to restoration of that state (Dent et al. 2002).

Correspondingly, in a descriptive sense the resilience of an ecological system can be defined as "the magnitude of disturbance that can be absorbed before the system shifts to another basin of attraction" (cf. Class 2 in Table 1; Gunderson and Holling 2002, Bellwood et al. 2004, Nyström 2006). In addition, some authors distinguish several characteristics or aspects of resilience, respectively (cf. Class $2 \mathrm{a}$ and $2 \mathrm{~b}$ in Table 1). The descriptive ecological definitions described above (Class 1-4 in Table 1) differ with respect to the criteria they provide as means to determine if a system is resilient and to what degree. In this article we focus on the extended-ecological definition of resilience in order to point to the concept of slow controlling variables, which can be used to operationalize resilience, and 
Fig. 1. Bifurcation diagram of a system described by a fast variable and a slow variable: the stable regimes are given by the blue and green solid lines and the boundary of the basins of attraction, i.e., unstable state, by the dashed line. ET1 and ET2 represent ecological threshold points (modified from Scheffer and Carpenter 2003).

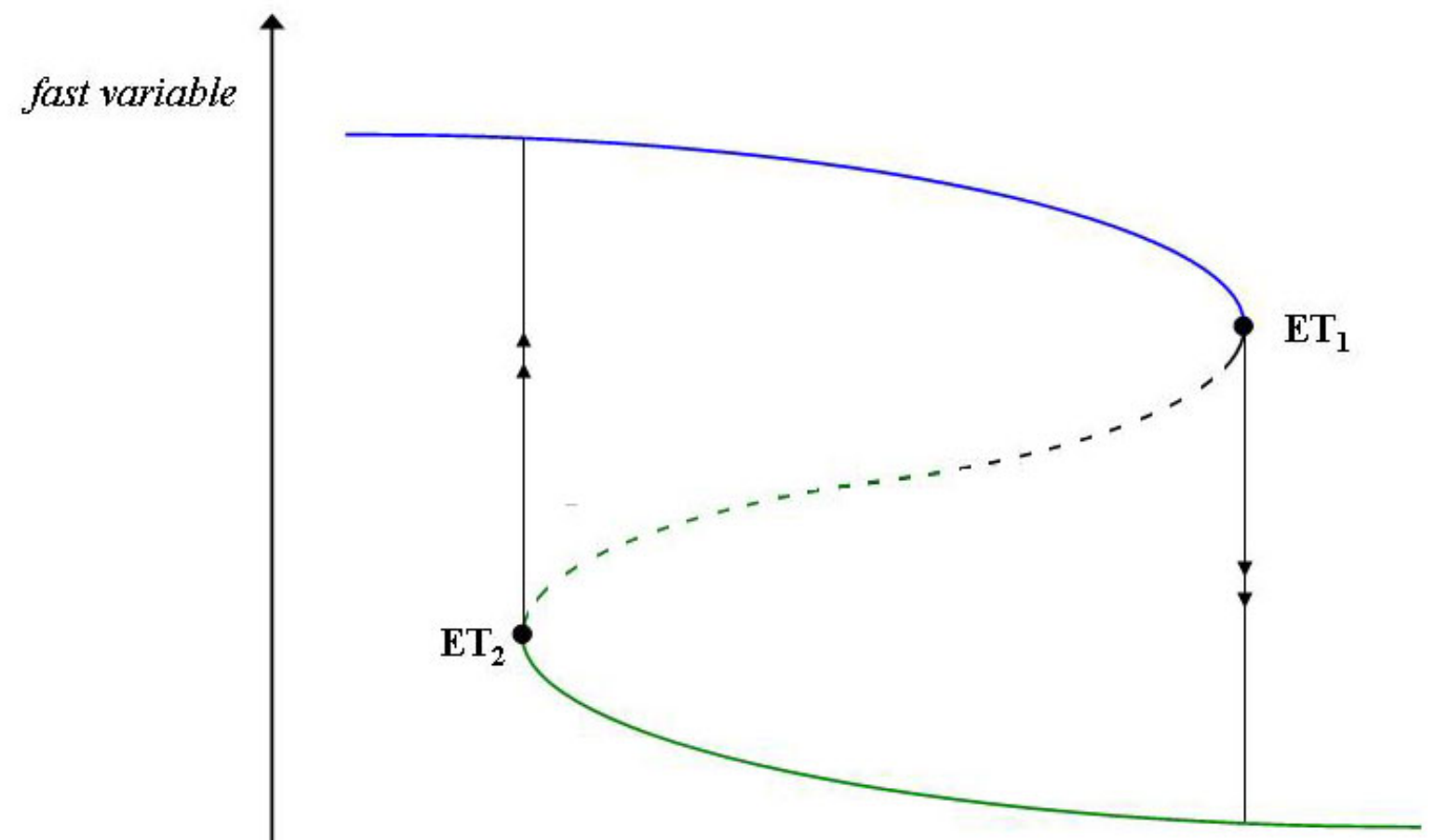

slow variable

thus to the importance of a quantitative and measurable approach to resilience.

Indeed, a crucial question for scientific progress is: are there any possibilities to estimate or measure the resilience of an ecosystem? Any operational interpretation of resilience means to specify resilience "to what" and "of what" (cf., Class 4 in Table 1; Carpenter et al. 2001) and channels into a comprehensive resilience analysis (Walker et al. 2002, Brand 2005). This also means to inquire which of the criteria for resilience described in definition Classes 1-4 are in fact meant as criteria that must be measured to assess and/ or quantify the resilience of an ecosystem.
The"to-what part" of the analysis explicates to what exactly a certain regime of an ecosystem should be resilient. This corresponds to specifying the disturbance regime, e.g., the kind of disturbances, their frequency, and intensity (Pickett and White 1985, White and Jentsch 2001), which may include both human disturbances, e.g., pollution pulses or habitat fragmentation, and natural disturbances, e. g., hurricanes or floods, as well as possible multiplicative effects (Vinebrooke et al. 2004).

The subsequent "of-what part" explicates the specific regime that is meant to be resilient to the identified disturbance regime. This part of the analysis is comprised of several steps. Step one 
means to assess which ecosystem processes or ecosystem services (see Jax 2005) of the regime are of primary concern on which spatial and temporal scale (Walker et al. 2002). Step two explicates the self-identity of the selected regime delimited in step one. This includes explicating the precise boundary of the regime, the set of variables of interest, and the expected internal degree of relationships, as well as the component resolution (Jax et al. 1998, 2006, Cumming et al. 2005). Step one and step two are dependent on societal values or normative judgments and should therefore incorporate environmental assessment procedures and participative deliberations (Plachter 1994, Jax and Rozzi 2004).

Apparently, the overall aim is to assess if the ecosystem is and remains within the regime of concern, which has been identified in the previous steps. Thus, step three specifies the variables and mechanisms that control the specific position of an ecosystem within state space. There are two options. The first option is to investigate empirically the value of the slow variables of a regime and plot it in a bifurcation diagram, as considered in Fig. 1. The amount of resilience is then measured as the distance between the current value of the slow variable and the critical value (Carpenter et al. 2001, Walker et al. 2002, Peterson et al. 2003, Bennett et al. 2005), which is termed precariousness (Walker et al. 2004). It may be possible to predict the position of an ecological threshold either by studying return time and standard deviations of a fast variable (Wissel 1984, Carpenter and Brock 2006) or by the repeated calculation of the Fisher information of a regime (Mayer et al. 2006).

The second option of step three refers to the amount of resilience mechanisms inherent in the desirable regime. Resilience mechanisms include (a) critical functional groups and functional important species, such as top predators or keystone species (Folke et al. 2004, Bellwood et al. 2004, Micheli and Halpern 2005), (b) ecological redundancy and response diversity within functional groups (Walker 1995, Peterson et al. 1998, Elmqvist et al. 2003, Hooper et al. 2005, Nyström 2006); and (c) the existence of a matrix of support areas at the landscape scale that provide potential colonists to compensate for the loss of species at the local scale (Bengtsson et al. 2003, Hughes et al. 2005). The amount of resilience mechanisms may be a measure to assess the relative resilience of the desirable regime to the given disturbances (cf., Allen et al. 2005).
The message of this section is that in a descriptive interpretation resilience can be a clearly specified and delimited stability concept. It is in this sense that resilience represents a quantitative and measurable concept that can be used for achieving progress in ecological science.

\section{RESILIENCE AS A BOUNDARY OBJECT}

In contrast to the use as a descriptive concept, resilience is increasingly viewed in a rather vague and malleable meaning. In the 1990s several scholars discovered the concept as an important tool to measure sustainability (Arrow et al. 1994, Perrings et al. 1995, Folke et al. 1996, Levin et al. 1998). Since then resilience has been used by various scientific disciplines, for instance economics (Farber 1995, Batabyal 1998, Perrings and Stern 2000, Brock et al. 2002, Perrings 2006), political science (Olsson et al. 2006), sociology (Adger 2000), or planning (Pickett et al. 2004), and each discipline has provided specific definitions (cf., Class 5-10 in Table 1). Moreover, resilience has been related to other scientific concepts such as carrying capacity (Seidl and Tisdell 1999), critical natural capital (Deutsch et al. 2003), strong sustainability (Arrow et al. 1995, Ott 2003, Ott and Döring 2004), globalization (Armitage and Johnson 2006), justice (Adger 2003), and adaptive comanagement (Berkes et al. 2003, Olsson et al. 2004).

In particular, resilience is increasingly interpreted in a broader meaning across disciplines as a way of thinking, a perspective or even paradigm for analyzing social-ecological systems (Folke et al. 2002, Folke 2003, Anderies et al. 2006, Folke 2006, Walker et al. 2006). Some authors expand theories or concepts drawn from ecological systems, e.g., alternative stable regimes, panarchy, or ecological redundancy, to examine social, political, and institutional systems (e.g., Gunderson and Holling 2002, Berkes et al. 2003, Allison and Hobbs 2004). Much research aims at a general theory for the resilience of whole social-ecological systems (cf., Class 8 in Table 1, Anderies et al. 2006). It is in this sense that resilience incorporates the capacity of social-ecological systems to cope with, adapt to, and shape change and learn to live with uncertainty and surprise (Folke 2003, 2006).

Thus, we suggest that resilience has become a "boundary object." Within the field of science and technology studies, this signifies a term that 
facilitates communication across disciplinary borders by creating shared vocabulary although the understanding of the parties would differ regarding the precise meaning of the term in question (Star and Griesemer 1989). Boundary objects are able to coordinate different groups without a consensus about their aims and interests. If they are both open to interpretation and valuable for various scientific disciplines or social groups, boundary objects can be highly useful as a communication tool in order to bridge scientific disciplines and the gap between science and policy (Eser 2002, Cash et al. 2003). Indeed, it is this vagueness and malleability, i.e., the potential variety of interpretations or applications of the term that makes boundary objects politically successful (Eser 2002). For example, the boundary object sustainability has been highly successful in providing the common ground for ecologists and economists, which were formerly thought contrary, to engage together for the needs of future generations. In addition, the concept has helped to reconcile contrasting interests of industrial and developing countries (UNEP 2002).

But there is a fundamental drawback to this. Boundary objects can in fact be a hindrance to scientific progress. For example, the meaning of the term sustainability is highly diluted and unclear. The three-pillar conception of sustainability, i.e., development in economic, social, and ecological systems, has been reduced to a listing of any societal objectives that agents happen to think important. That means that the extension of the term has become extremely wide. This is due to the fact that the catchword sustainable development enables different scientific disciplines or social groups to justify their particular interest with respect to an accepted and ethically legitimated, societal goal (Ott 2003, Grunwald 2004b). It may thus even hide conflicts and power relations when different persons agree on the need for sustainability when in fact meaning different things by it. Therefore, sustainability is generally conceived as arbitrary or as an illusion and within sustainability science there is confusion on how to operationalize and apply the concept (Grunwald 2004a). To foster conceptual clarity and practical relevance some authors have suggested a clear and specified theory of sustainability, which is characterized by both a narrow extension and a clear intension of the term (Kopfmüller et al. 2001, 2006, Ott 2003, Ott and Döring 2004, Kates et al. 2005).
These insights indicate that, metaphorically spoken, boundary objects are Janus-faced, i.e. they are inherently ambivalent. They may have positive and negative aspects in terms of scientific progress and political success. What does that mean for a scientific concept of resilience?

\section{DISCUSSION}

In this section we synthesize the points made in the previous sections and discuss some implications for a fruitful conceptual structure of resilience. Resilience is a two-faced concept. On the one hand, the concept is used as a descriptive, ecological concept (e.g., Walker 2002, Gunderson and Holling 2002, Bellwood et al. 2004, Nyström 2006) whereas, on the other hand, it represents a boundary object with a rather wide and vague meaning (e.g., Gunderson and Holling 2002, Adger et al. 2003, Folke 2003, Hughes et al 2005, Folke 2006, Walker et al. 2006). As a result, the original ecological concept of resilience first defined by Holling (1973) has been transformed considerably. This becomes apparent in several points.

First, the specific meaning of resilience gets diluted and increasingly unclear. This is due to the use of the concept (a) with many different intensions and (b) with a very wide extension. For example, Hughes et al. (2005) suggest several key components of resilience for marine regions. These include leadership and insight, sustained mobilization of national and international aid, cultural and ecological diversity, development of multiscale social networks, and the resolution of local civil unrest. Apparently, Hughes et al. (2005) apply both the social-ecological definition and the metaphoric definition of resilience (cf., Classes $8 \mathrm{a}$ and 9 in Table 1) in order to link an ecological-descriptive meaning of resilience to governance structures, economics and society. As a result, however, the concept of resilience includes very much, from international aid and leadership to ecological diversity, and it is for this reason why the meaning of resilience gets diluted and unclear, as for logical reasons any concept that encompasses very much, i.e., wide extension, must lose specific meaning, i.e., clear intension (Ott 2003). Indeed, regarding the interpretation of resilience put forward by Hughes et al. (2005), it gets difficult to decide whether a certain state is resilient or not or to specify the 
particular degree of resilience inherent in a certain state.

Second, a broad concept of resilience often includes normative dimensions. Following the interpretation of Hughes et al. (2005) resilience represents a hybrid concept containing a blending of descriptive and normative aspects, as international aid, cultural diversity, and the resolution of local civil unrest represent instrumental and eudaemonistic values. The fact that a broad concept of resilience includes normative dimensions is not surprising. We see other boundary objects floating between descriptive and normative meanings, as in the case of biodiversity, i.e., biodiversity in the specific scientific sense of diversity at the level of genes, species, and ecosystems vs. biodiversity in the sense of the ominous value of life on earth (Eser 2002). But the important point is that these normative aspects within a broad concept of resilience ought to be made explicit and, whenever possible, justified ethically (U. Eser and T. Potthast, personal communication).

Third, the term resilience is used ambiguously as divergent conceptions of resilience are proposed. There are at least 10 different approaches to resilience. Each approach emphasizes different aspects of resilience with respect to the specific interest. The ecological aspect is stressed by ecologists, whereas the political and institutional aspects are stressed by sociologists, etc. Thus, the term resilience is used ambiguously for fundamentally different intensions (cf., Class 1-10 in Table 1). The direct consequences are trade-offs between social and environmental objectives within a conception of resilience, which may be difficult to handle.

Fourth, the original ecological dimension of resilience is about to vanish. Our impression is that recent studies increasingly stress the social, political, and institutional dimensions of resilience (e.g., Folke 2002, Olsson et al. 2004, 2006, Janssen 2006) or address whole social-ecological systems (e.g., Adger et al. 2005, Hughes et al. 2005, Folke 2006, Walker et al. 2006), whereas genuinely ecological studies of resilience get rare (but cf., Bellwood et al. 2004, Nyström 2006).

Finally, resilience is increasingly conceived as a perspective, rather than a clear and well-defined concept. Recently, resilience has been conceived either as a way of thinking, as an approach to address social processes, such as social learning, leadership and adaptive governance (cf. Class $8 \mathrm{~b}$ in Table 1; Folke 2006) or as a metaphor for the flexibility of a social-ecological system over the long term (cf., Class 9 in Table 1; Pickett et al. 2004). According to Anderies et al. (2006), resilience is better described as a collection of ideas about how to interpret complex systems. As a result, the meaning of resilience gets increasingly vague and unspecified.

How to evaluate this conceptual development of resilience? We suggest on the one side that both conceptual clarity and practical relevance of resilience are critically at stake. A scientific concept of resilience must have a clear and specified meaning that is constantly used in the same way. In particular, it must be possible (a) to specify the particular objects the concept refers to, (b) to decide whether particular states in nature are resilient or nonresilient and it should be possible (c) to assess the degree of resilience of a certain state (cf., Grunwald 2004a,b, Jax 2006). In fact, the quality of the term resilience is strongly dependent on the ability to exclude phenomena that do not meet this term, as both operationalization and application with respect to environmental management are strongly dependent on a clear and delimited meaning of the term (Pickett et al. 2004).

On the other side, however, we propose that the increased vagueness and malleability of resilience is highly valuable because it is for this reason that the concept is able to foster communication across disciplines and between science and practice (cf., Eser 2002). Therefore, it is not the suggestion to eradicate this vagueness and ambiguousness entirely but to grasp the ambivalent character of boundary objects and, hence, of a wide and vague use of resilience.

To counterbalance the positive and negative aspects of the conceptual development of resilience we, thus, argue for division of labor in a scientific sense. Resilience, conceived as a descriptive concept, should be a clear, well defined, and specified concept that provides the basis for operationalization and application within ecological science. For the sake of clarity, this meaning may be dubbed ecological resilience/ecosystem resilience, for ecological systems, or just resilience if applied to systems other than ecological, e.g., climatic systems. In contrast, resilience conceived as a boundary object should be designed in a manner to 
foster interdisciplinary work. In this sense, resilience constitutes a vague and malleable concept that is used as a transdisciplinary approach to analyze social-ecological systems. For greater clarity this meaning may be termed socialecological resilience (as in Folke 2006).

Responses to this article can be read online at:

http://www.ecologyandsociety.org/voll2/iss 1/art23/responses/

\section{Acknowledgments:}

This manuscript was greatly improved over earlier drafts by following suggestions made by Lance Gunderson, Chistoph Görg, Christopher MensahBonsu, Christian Lampei, and two anonymous reviewers. We thank Florin Brand for help in creating the figure. This work was supported in part by a Ph.D. scholarship for Fridolin Brand provided by the Deutsche Bundesstiftung Umwelt (DBU), Germany.

\section{LITERATURE CITED}

Adger, W. N. 2000. Social and ecological resilience: are they related? Progress in Human Geography 24 (3):347-364.

Adger, W. N. 2003. Building resilience to promote sustainability: an agenda for coping with globalisation and promoting justice. International Human Dimensions Programme on Global Environmental Change (IHDP) Newsletter 2, Bonn, Germany.

Adger, W. N. 2006. Vulnerability. Global Environmental Change 16(3):268-281.

Adger, W. N., Hughes, T. P., C. Folke, S. R. Carpenter, and J. Rockström. 2005. Socialecological resilience to coastal disasters. Science 309:1036-1039.

Allen, C. R., L. Gunderson, and A. R. Johnson. 2005. The use of discontinuities and functional groups to assess relative resilience in complex systems. Ecosystems 8(8):958-966.
Allison, H. E., and R. J. Hobbs. 2004. Resilience, adaptive capacity, and the "Lock-in Trap" of the western Australian agricultural region. Ecology and Society 9(1):3. [online] URL: http://www.ecologya ndsociety.org/vol9/iss1/art3.

Anderies, J. M., B. H. Walker, and A. P. Kinzig. 2006. Fifteen weddings and a funeral: case studies and resilience-based management. Ecology and Society 11(1):21. [online] URL: http://www.ecolog yandsociety.org/vol11/iss1/art21/.

Armitage, D., and D. Johnson. 2006. Can resilience be reconciled with globalization and the increasingly complex conditions of resource degradation in Asian coastal regions? Ecology and Society 11(1):2. [online] URL: http://www.ecology andsociety.org/vol11/iss 1/art2/.

Arrow, K., B. Bolin, R. Costanza, P. Dasgupta, C. Folke, C. S. Holling, B.-O. Jansson, S. Levin, K.-G. Mäler, C. Perrings, and D. Pimental. 1995. Economic growth, carrying capacity, and the environment. Science 268:520-521.

Batabyal, A. A. 1998. The concept of resilience: retrospect and prospect. Environment and Development Economics 3:235-239.

Bellwood, D. R., T. P. Hughes, C. Folke, and M. Nyström. 2004. Confronting the coral reef crisis. Nature 429:827-833.

Bengtsson, J., P. Angelstam, T. Elmqvist, U. Emanuelsson, C. Folke, M. Ihse, F. Moberg, and M. Nyström. 2003. Reserves, resilience and dynamic landscapes. Ambio 32(6):389-396.

Bennett, E. M., G. S. Cumming, and G. D. Peterson. 2005. A systems model approach to determining resilience surrogates for case studies. Ecosystems 8:945-957.

Berkes, F., J. Colding, and C. Folke, editors. 2003. Navigating social-ecological systems: building resilience for complexity and change. Cambridge University Press, Cambridge, UK.

Brand, F. 2005. Ecological resilience and its relevance within a theory of sustainable development. UFZ-Report 03/2005. UFZ Centre for Environmental Research Leipzig-Halle, Department of Ecological Modelling, Leipzig, Germany. 
Briske, D. D., S. D. Fuhlendorf, and F. E. Smeins. 2006. A unified framework for assessment and application of ecological thresholds. Rangeland Ecology and Management 59(3):225-236.

Brock, W. A., K.-G. Mäler, and C. Perrings. 2002. Resilience and sustainability: the economic analysis of nonlinear dynamic systems. Pages 261-289 in L. H. Gunderson and C. S. Holling, editors. Panarchy: understanding transformations in human and natural systems. Island Press, Washington, D.C., USA.

Carpenter, S. R., and K. L. Cottingham. 1997. Resilience and restoration of lakes. Ecology and Society 1(1):2. [online] URL: http://www.ecologya ndsociety.org/vol1/iss1/art2/.

Carpenter, S. R., B. Walker, J. M. Anderies, and N. Abel. 2001. From metaphor to measurement: resilience of what to what? Ecosystems 4:765-781.

Carpenter, S. R., and W. A. Brock. 2006. Rising variance: a leading indicator of ecological transition. Ecology letters 9(3):308-315.

Carpenter, S. R., and C. Folke. 2006. Ecology for transformation. Trends in Ecology and Evolution 21 (6):309-315.

Cash, D. W., W. C. Clark, F. Alcock, N. M. Dickson, N. Eckley, D. H. Guston, J. Jäger, and R. B. Mitchell. 2003. Knowledge systems for sustainable development. Proceedings of the National Academy of Sciences USA 100 (14):8086-8091.

Cumming, G. S., and J. Collier. 2005. Change and identity in complex systems. Ecology and Society 10(1):29. [online] URL: http://www.ecologyandsoc iety.org/vol10/iss 1/art29/.

Cumming, G. S., G. Barnes, S. Perz, M. Schmink, K. E. Sieving, J. Southworth, M. Binford, R. D. Holt, C. Stickler and T. Van Holt. 2005. An exploratory framework for the empirical measurement of resilience. Ecosystems 8:975-987.

Deutsch, L., C. Folke, and K. Skanberg. 2003. The critical /natural capital of ecosystem performance as insurance for human well-being. Ecological Economics 44:205-217.
Didham, R. K. 2006. When are alternative stable states more likely to occur? Oikos 113(2):357-362.

Elmqvist, T., C. Folke, M. Nyström, G. Peterson, J. Bengtsson, B. Walker, and J. Norberg. 2003. Response diversity, ecosystem change, and resilience. Frontiers in ecology and the environment 1(9):488-494.

Eser, U. 2002. Der Wert der Vielfalt: "Biodiversität" zwischen Wissenschaft, Politik und Ethik. Pages 160-181 in M. Bobbert, M. Düwel and K. Jax, editors. Umwelt -Ethik-Recht. Francke Verlag, Tübingen, Germany.

Farber, S. 1995. Economic resilience and economic policy. Ecological Economics 15:105-107.

Foley, J. A., R. DeFries, G. P. Asner, C. Barford, G. Bonan, S. R. Carpenter, F. S. Chapin, M. T. Coe, G. C. Daily, H. K. Gibbs, J. H. Helkowski, T. Holloway, E. A. Howard, C. J. Kucharik, C. Monfreda, J. A. Patz, J. C. Prentice, N. Ramankutty, and P. K. Snyder. 2005. Global consequences of land use. Science 309:570-574.

Folke, C. 2003. Freshwater for resilience: a shift in thinking. Philosophical Transactions of the Royal Society London B 358:2027-2036.

Folke, C. 2006. Resilience: the emergence of a perspective for social-ecological system analyses. Global Environmental Change 16(3):253-267.

Folke, C., C. S. Holling, and C. Perrings. 1996. Biological diversity, ecosystems, and the human scale. Ecological Applications 6(4):1018-1024.

Folke, C., S. Carpenter, T. Elmqvist, L. Gunderson, C. S. Holling, B. Walker, J. Bengtsson, F. Berkes, J. Colding, K. Danell, $M$. Falkenmark, L. Gordon, R. Kasperson, N. Kautsky, A. Kinzig, S. Levin, K.-G. Mäler, F. Moberg, L. Ohlsson, P. Olsson, E. Ostrom, W. Reid, J. Rockström, H. Savenije, and U. Svedin. 2002. Resilience and sustainable development: building adaptive capacity in a world of transformations. Scientific Background Paper on Resilience for the process of The World Summit on Sustainable Development on behalf of The Environmental Advisory Council to the Swedish Government. 
Folke, C., S. Carpenter, S., B. Walker, M. Scheffer, T. EImqvist, L. Gunderson, and C. S. Holling. 2004. Regime shifts, resilience, and biodiversity in ecosystem management. Annual Review of Ecology, Evolution and Systematics 35:557-581.

Grimm, V. and C. Wissel. 1997. Babel, or the ecological stability discussions: an inventory and analysis of terminology and a guide for avoiding confusion. Oecologia 109:323-334.

Groffman, P. M, J. S. Baron, T. Blett, A. J. Gold, I. Goodman, L. H. Gunderson, B. M. Levinson, M. A. Palmer, H. W. Paerl, G. D. Peterson, N. L. Poff, D. W. Rejeski, J. F. Reynolds, M. G. Turner, K. C. Weathers, and J. Wiens. 2006. Ecological thresholds: the key to successful environmental management or an important concept with no practical application? Ecosystems 9:1-13.

Grunwald, A. 2004a. Die gesellschaftliche Wahrnehmung von Nachhaltigkeitsproblemen und die Rolle der Wissenschaften. Pages 313-341 in D. Ipsen and J. C. Schmidt, editors. Dynamiken von Nachhaltigkeit. Metropolis, Marburg, Germany.

Grunwald, A. 2004b. Nachhaltigkeit begreifen: Zwischen Leitbild und Trugbild. GAIA 13(1):49-50.

Gunderson, L. H. 2000. Ecological Resilience-in theory and application. Annual Review of Ecology and Systematics 31:425-439.

Gunderson, L. H., and C. S. Holling, editors. 2002. Panarchy: understanding transformations in human and natural systems. Island Press, Washington, D.C., USA.

Gunderson, L. H., and L. Pritchard, editors. 2002. Resilience and the behaviour of large-scale systems. Island Press, Washington, D.C., USA.

$$
-->
$$

Holling, C. S. 1973. Resilience and stability of ecological systems. Annual Review of Ecology and Systematics 4:1-23.

Holling, C. S. 1986. The resilience of terrestrial ecosystems, local surprise and global change. Pages 292-317 in W. C. Clark and R. E. Munn, editors. Sustainable development of the biosphere. Cambridge University Press, Cambridge, UK.
Holling, C. S. 1992. Cross-scale morphology, geometry, and dynamics of ecosystems. Ecological Monographs 62(4):447-502.

Holling, C. S. 1996. Engineering resilience versus ecological resilience. Pages 31-44 in P. C. Schulze, editor. Engineering within ecological constraints. National Academy Press, Washington, D.C., USA.

Holling, C. S. 2001. Understanding the complexity of economic, ecological, and social systems. Ecosystems 4:390-405.

Hooper, D. U., F. S. Chapin, III, J. J. Ewel, A. Hector, P. Inchausti, S. Lavorel, J. H. Lawton, D. M. Lodge, M. Loreau, S. Naeem, B. Schmid, H. Setälä, A. J. Symstad, J. Vandermeer, and D. A. Wardle. 2005. Effects of biodiversity on ecosystem functioning: a consensus of current knowledge. Ecological Monographs 75(1):3-35.

Hughes, T. P., D. R. Bellwood, C. Folke, R. S. Steneck, and J. Wilson. 2005. New paradigms for supporting the resilience of marine ecosystems. Trends in Ecology and Evolution 20(7):380-386.

Janssen. M. A. 2006. Historical institutional analysis of social-ecological systems. Journal of Institutional Economics 2(2):127-131.

Janssen, M. A., M. L. Schoon, W. Ke, and K. Börner. 2006. Scholarly networks on resilience, vulnerability and adaptation within the human dimensions of global environmental change. Global Environmental Change 16(3):240-252.

Jax, K. 2005. Function and "functioning" in ecology: what does it mean? Oikos 111:641-648.

Jax, K. 2006. The units of ecology: definition and application. Quarterly Review of Biology $\mathbf{8 1}$ (3):237-258 .

Jax, K., C. G. Jones, and S. T. A. Pickett. 1998. The self-identity of ecological units. Oikos 82:253-264.

Jax, K., and R. Rozzi. 2004. Ecological theory and values in the determination of conservation goals: examples from the temperate regions of Germany, USA and Chile. Revista Chilena de Historia Natural 77:349-366. 
Kates, R. W., W. C. Clark, R. Corell, J. M. Hall, C. C. Jaeger, I. Lowe, J. J. McCarthy, H. J. Schellnhuber, B. Bolin, N. M. Dickson, S. Faucheux, G. C. Gallopin, A. Grübler, B. Huntley, J. Jäger, N. S. Jodha, R. E. Kasperson, A. Mabogunje, P. Matson, H. Mooney, B. Moore III, T. O'Riordan, and U. Svedin. 2001. Sustainability science. Science 292:641-642.

Kates, R. W., T. M. Parris, and A. A. Leiserowitz. 2005. What is sustainable development? Goals, indicators, values, and practice. Environment 47 (3):8-21.

Kopfmüller, J., editor. 2006. Ein Konzept auf dem Prüfstand: Das integrative Nachhaltigkeitskonzept in der Forschungspraxis. Edition sigma, Berlin, Germany.

Kopfmüller, J., V. Brandl, J. Jörissen, M. Paetau, G. Banse, R. Coenen, and A. Grunwald. 2001. Nachhaltige Entwicklung integrativ betrachtet: Konstitutive Elemente, Regeln, Indikatoren. Edition sigma, Berlin, Germany.

Levin, S. A. 1998. Ecosystems and the biosphere as complex adaptive systems. Ecosystems 1:431-436.

Levin, S. A., S. Barrett, S. Aniyar, W. Baumol, C. Bliss, B. Bolin, P. Dasgupta, P. Ehrlich, C. Folke, I.-M. Gren, C. S. Holling, A. Jansson, B.-O. Jansson, K.-G. Mäler, D. Martin, C. Perrings, and E. Sheshinski. 1998. Resilience in natural and socioeconomic systems. Environment and Development Economics 3:221-235.

Ludwig, D., B. Walker, and C. S. Holling. 1997. Sustainability, stability, and resilience. Conservation Ecology 1(1):7. [online] URL: http://www.consecol. org/vol1/iss1/art7/.

Ludwig, D., B. Walker, and C. S. Holling. 2002. Models and metaphors of sustainability, stability, and resilience. Pages 21-48 in L. H. Gunderson, and L. Pritchard Jr., editors. Resilience and the behavior of large-scale systems. Island Press, Washington, D.C., USA.

Mayer, A. L., C. W. Pawlowski, and H. Cabezas. 2006. Fisher information and dynamic regime changes in ecological systems. Ecological Modelling 195:72-82.

Micheli, F., and Halpern, B. S. 2005. Low functional redundancy in coastal marine assemblages. Ecology Letters 8:391-400.
Millenium Ecosystem Assessment (MEA). 2005. Ecosystems and human well being: synthesis. Island Press, Washington, D.C., USA.

Nyström, M. 2006. Redundancy and response diversity of functional groups: implications for the resilience of coral reefs. Ambio 35(1):30-35.

Olsson, P., C. Folke, and F. Berkes. 2004. Adaptive comanagement for building resilience in socialecological systems. Environmental Management 34 (1):75-90.

Olsson, P., L. H. Gunderson, S. R. Carpenter, P. Ryan, L. Lebel, C. Folke, and C. S. Holling. 2006. Shooting the rapids: navigating transitions to adaptive governance of social-ecological systems. Ecology and Society 11(1):18. [online] URL: http:/ /www.ecologyandsociety.org/vol11/iss 1/art18/.

Ott, K. 2001. Eine Theorie 'starker' Nachhaltigkeit. Natur und Kultur 2(1):55-75.

Ott, K. 2003. The case for strong sustainability. Pages 59-64 in K. Ott, and P. P. Thapa, editors. Greifswald's environmental ethics. Steinbecker Verlag Ulrich Rose, Greifswald, Germany.

Ott, K., and R. Döring. 2004. Theorie und Praxis starker Nachhaltigkeit. Metropolis, Marburg, Germany.

Perrings, C. A. 2006. Resilience and sustainable development. Environment and Development Economics 11:417-427.

Perrings, C. A., K.-G. Mäler, C. Folke, C. S. Holling, and B.-O. Jansson, editors. 1995. Biodiversity conservation, problems and policies. Kluwer Academic, Dordrecht, The Netherlands.

Perrings, C.A., and B. Walker. 1997. Biodiversity, resilience and the control of ecological-economic systems: the case of fire-driven rangelands. Ecological Economics 22:73-83.

Perrings, C. A., and D. I. Stern. 2000. Modelling Loss of Resilience in Agroecosystems: Rangelands in Botswana. Environmental and Resource Economics 16:185-210.

Peterson, G., C. R. Allen, and C.S. Holling. 1998. Ecological resilience, biodiversity, and scale. Ecosystems 1:6-18. 
Peterson, G. D., S. R. Carpenter, and W.A. Brock. 2003. Uncertainty and the management of multistate ecosystems: an apparently rational route to collapse. Ecology 84(6):1403-1411.

Pickett, S. T.A., and P. S. White. 1985. The ecology of natural disturbance and patch dynamics. Academic Press, Orlando, Florida, USA.

Pickett, S. T. A., J. Kolasa, and C. G. Jones. 1994. Ecological understanding. Academic Press, London, UK.

Pickett, S. T. A., M. L. Cadenasso, and J. M. Grove. 2004. Resilient cities: meaning, models, and metaphor for integrating the ecological, socioeconomic, and planning realms. Landscape and Urban Planning 69:369-384.

Plachter, H. 1994. Methodische Rahmenbedingungen für synoptische Bewertungsverfahren im Naturschutz. Zeitschrift für Ökologie und Naturschutz 3:87-105.

Scheffer, M., and S. R. Carpenter. 2003. Catastrophic regime shifts in ecosystems: linking theory to observation. Trends in Ecology and Evolution 18(12):848-656.

Schröder, A., L. Persson, and A. M. De Roos. 2005. Direct experimental evidence for alternative stable states: a review. Oikos 110(1):3-19.

Seidl, I., and C. A. Tisdell. 1999. Carrying capacity reconsidered: from Malthus' population theory to cultural carrying capacity. Ecological Economics 31:395-408.

Star, S. L., and J. R. Griesemer. 1989. Institutional ecology, 'translations' and boundary objects: amateurs and professionals in Berkeley's museum of vertebrate zoology, 1907-39. Social Studies of Science 19(3):387-420.

UNEP (United Nations Environment Program). 2002. Integrating environment and development 1972-2002. Pages 2-27 in UNEP. Global Environmental Outlook 3: Past, present and future perspectives. Earthscan, London, UK.

Vinebrooke, R. D., K. L. Cottingham, J. Norberg, M. Scheffer, S. I. Dodson, S. C. Maberly, and U. Sommer. 2004. Impacts of multiple stressors on biodiversity and ecosystem functioning: the role of species co-tolerance. Oikos 104:451-457.
Walker, B. 1995. Conserving biological diversity through ecosystem resilience. Conservation Biology 9(4):747-752.

Walker, B. 2002. Ecological resilience in grazed rangelands: a generic case study. Pages 183-194 in L. H. Gunderson, and L. Pritchard, editors. Resilience and the behavior of large-scale systems. Island Press, Washington, D.C., USA.

Walker, B., A. Kinzig, and J. Langridge. 1999. Plant attribute diversity, resilience, and ecosystem function: the nature and significance of dominant and minor species. Ecosystems 2:95-113.

Walker, B., S. Carpenter, J. Anderies, N. Abel, G. Cumming, M. Janssen, L. Lebel, J. Norberg, G. D. Peterson, and R. Pritchard. 2002. Resilience management in social-ecological systems: a working hypothesis for a participatory approach. Ecology and Society 6(1):14. [online] URL: http:// www.ecologyandsociety.org/vol6/iss 1/art14/.

Walker, B., and J. A. Meyers. 2004. Thresholds in ecological and social-ecological systems: a developing database. Ecology and Society 9(2):3. [online] URL: http://www.ecologyandsociety.org/vol9/ iss $2 / \operatorname{art} 3 /$.

Walker, B., C. S. Holling, Carpenter, S. R., and A. Kinzig. 2004. Resilience, adaptability and transformability in social-ecological systems. Ecology and Society 9(2):5. [online] URL: http://w ww.ecologyandsociety.org/vol9/iss2/art5/.

Walker, B., L. Gunderson, A. Kinzig, C. Folke, S. Carpenter, and L. Schultz. 2006. A handful of heuristics and some propositions for understanding resilience in social-ecological systems. Ecology and Society 11(1):13. [online] URL: http://www.ecolog yandsociety.org/vol11/iss1/art13/.

Wallington, T. J., R. J. Hobbs, and S. A. Moore. 2005. Implications of current ecological thinking for biodiversity conservation: a review of the salient issues. Ecology and Society 10(1):15. [online] URL: http://www.ecologyandsociety.org/vol10/iss1/ $\underline{\operatorname{art} 15 / .}$.

Westley, F., S. R. Carpenter, W. A. Brock, C. S. Holling, and L. H. Gunderson. 2002. Why systems of people and nature are not just social and ecological systems. Pages 103-119 in L. H. 
Gunderson and C. S. Holling, editors. Panarchy: understanding transformations in human and natural systems. Island Press, Washington, D.C., USA.

White, P. S., and A. Jentsch. 2001. The search for generality in studies of disturbance and ecosystem dynamics. Progress in Botany 62:399-450.

Wissel, C. 1984. A universal law of the characteristic return time near thresholds. Oecologia 65:101-107. 